\title{
CAPITAL STRUCTURE PUZZLE
}

\section{by}

Stewart C. Myers

非1548-84

April 1984 
. THE CAPITAL STRUCTURE PUZZLE

Stewart C. Myers*

This paper's title is intended to remind you of Fischer Black's wel1-known note on "The Dividend Puzzle," which he closed by saying, "What should the corporation do about dividend policy? We don't know." [6, p.8] I will start by asking, "How do firms choose their capital structures?" Again, the answer is, "We don't know."

The capital structure puzzle is tougher than the dividend one. We know quite a bit about dividend policy. John Lintner's model of how firms set dividends [19] dates back to 1956, and it still seems to work. We know stock prices respond to unanticipated dividend changes, so it is clear that dividends have information content--this observation dates back at least to Miller and Modigliani (MM) in 1961 [27]. We do not know whether high dividend yield increases the expected rate of return demanded by investors, as adding taxes to the MM proof of dividend irrelevance suggests, but financial economists are at least hammering away at this issue.

By contrast, we know very little about capital structure. We do not know how firms choose the debt, equity or hybrid securities they issue. We have only recently discovered that capital structure changes convey information to investors. There has been little if any research testing whether the relationship between financial leverage and investors' required return is as 
the pure MM theory predicts. In general, we have inadequate understanding of corporate financing behavior, and of how that behavior affects security returns.

I do not want to sound too pessimistic or discouraged. We have accumulated many helpful insights into capital structure choice, starting with the most important one, MM's No Magic in Leverage Theorem (Proposition I) [31]. We have thought long and hard about what these insights imply for optimal capital structure. Many of us have translated these theories, or stories, of optimal capital structure into more or less definite advice to managers. But our theories don't seem to explain actual financing behavior, and it seems presumptuous to advise firms on optimal capital structure when we are so far from explaining actual decisions. I have done more than my share of writing on optimal capital structure, so I take this opportunity to make amends, and to try to push research in some new directions.

I will contrast two ways of thinking about capital structure:

1. A static tradeoff framework, in which the firm is viewed as setting a target debt-to-value ratio and gradually moving towards it, in much the same way $t$ hat a firm adjusts dividends to move towards a target payout ratio.

2. An old-fashioned pecking order framework, in which the firm prefers internal to external financing, and debt to equity if it issues securities. In the pure pecking order theory, the firm has no well-defined target debt-to-value ratio.

Recent theoretical work has breathed new life into the pecking order framework. I will argue that this theory performs at least as well as the static tradeoff theory in explaining what we know about actu 1 financing 
choices and their average impacts on stock prices.

Managerial and Neutral Mutation Hypotheses

I have arbitrarily, and probably unfairly, excluded "managerlal" theories which might explain firms' capital structure choices. ${ }^{1}$ I have chosen not to consider models which cut the umbilical cord that ties managers' acts to stockholders' interests.

I am also sidestepping Miller's idea of "neutral mutation." 2 He suggests that firms fall into some financing patterns or habits which have no material effect on firm value. The habits may make managers feel better, and since they do no harm, no one cares to stop or change them. Thus someone who identifies these habits and uses them to predict financing behavior would not be explaining anything important.

The neutral mutations idea is important as a warning. Given time and imagination, economists can usually invent some model that assigns apparent economic rational ity $t o$ any random event. But taking neutral mutation as a strict null hypothesis makes the game of research too tough to play. If an economist identifies costs of various financing strategies, obtains independent evidence that the costs are really there, and then builds a mode 1 based on these costs which explains firms' financing behavior, then some progress has been made, even if it proves difficult to demonstrate that, say, a type A financing strategy gives higher firm value than a type B. (In fact, we would never see type B if all firms follow value-maximizing strategies.)

There is another reason for not immediately embracing neutral mutations: we know investors are interested in the firm's financing choices, because 
stock prices change when the choices are announced. The change might be explained as an "information effect" having nothing to do with financing per se--but again, it is a bit too easy to wait until the results of an event study are in, and then to think of an information story to explain them. On the other hand, if one starts by assuming that managers have special information, builds a model of how that information changes financing choices, and predicts which choices will be interpreted by investors as good or bad news, then some progress has been made.

So this paper is designed as a one-on-one competition of the static tradeoff and pecking-order storles. If neither story explains actual behavior, the neutral mutations story will be there falthfully waiting.

\section{The Static Tradeoff Hypothesis}

A firm's optimal debt ratio is usually viewed as determined by a tradeoff of the costs and benefits of borrowing, holding the firm's assets and investment plans constant. The firm is portrayed as bal ancing the value of interest tax shields against varlous costs of bankruptcy or financial embarassment. Of course, there is controversy about how valuable the tax shields are, and which, if any, of the costs of financial embarassment are material, but these disagreements give only variations on a theme. The firm is supposed to substitute debt for equity, or equity for debt, until the value of the firm is maximized. Thus the debt-equity tradeoff is as 1llustrated in Fig. 1 .

Costs of adjustment. If there were no costs of adjustment, and the static tradeoff theory is correct, then each $f 1 \mathrm{rm}$ 's observed debt-to-value ratio 
should be its optimal ratio. However, there must be costs, and therefore lags, in adjusting to the optimum. Firms can not immediately offset the random events that bump them away from the optimum, so there should be some cross-sectional dispersion of actual debt ratios across a sample of firms having the same target ratio.

Large adjustment costs could possibly explain the observed wide variation in actual debt ratios, since firms would be forced into long excursions away from their optimal ratios. But there is nothing in the usial static tradeoff stories suggesting that adjustment costs are a first-order concern--in fact, they are rarely mentioned. Invoking them withas modelling them is a cop-out.

Any cross-sectional test of financing behavior should specify whether firms' debt ratios differ because they have different optimal ratios or because their actual ratios diverge from optimal ones. It is easy to get the two cases mixed up. For example, think of the early cross-sectional studies which attempted to test MM's Proposition I. These studies tried to find out whether differences in leverage affected the market value of the firm (or the market capitalization rate for its operating income). With hindsight, we can quickly see the problem: if adjustment costs are small, and each firm in the sample is at, or close to its optimum, then the in-sample dispersion of debt ratios must reflect differences in risk or in other variables affecting optimal capital structure. But then MM's Proposition I cannot be tested unless the effects of risk and other variables on firm value can be adjusted for. By now we have learned from experience how hard it is to hold "other things constant" in cross-sectional regressions.

of course, one way to make sense of these tests is to assume that adjustment costs are small, but managers don't know, or don't care, what the 
optimal debt ratio is, and thus do not stay close to it. The researcher then assumes some (usually unspecified) "managerial" theory of capital structure choice. This may be a convenient assumption for a cross-sectional test of MM's Proposition I, but not very helpful if the object is to understand financing behavior. ${ }^{3}$

But suppose we don't take this "managerial" fork. Then if adjustment costs are small, and firms stay near their target debt ratios, I find it hard to understand the observed diversity of capital structures across firms that seem similar in a static tradeoff framework. If adjustment costs are large, so that some firms take extended excursions away from their targets, then we ought to give less attention to refining our static tradeoff stories and relatively more to understanding what the adiustment costs are, why $c$ hey are so important, and how rational managers would respond to them.

But I am getting ahead of my story. On to debt and taxes.

Debt and taxes. Miller's famous "Debt and Taxes" paper [26] cut us loose from the extreme implications of the original MM theory, which made interest tax shields so valuable that we could not explain why all firms were not awash in debt. Miller described an equilibrium of aggregate supply and demand for coporate debt, in which personal income taxes paid by the marginal investor in corporate debt just offset the corporate tax saving. However, since the equilibrium only determines aggregates, debt policy should not matter for any single tax-paying firm. Thus Miller's model allows us to explain the dispersion of actual debt policies without having to introduce non-value-maximizing managers. ${ }^{4}$

Trouble is, this explanation works only if we assume that all firms face approximately the same marginal tax rate, and that is an assumption we can 
immediately reject. The extensive trading of depreciation tax shields and investment tax credits, thraugh financial leases and other devices, proves that plenty of firms face low marginal rates. 5

Given significant differences in effective marginal tax rates, and given that the static tradeoff theory works, we would expect to find a strong tax effect in any cross-sectional test, regardless of whose theo ry of debt and taxes you believe.

Figure 2 plots the net tax gain from corporate borrowing against the expected realizable tax shield from a future deduction of one dollar of interest paid. For some firms this number is 46 cents, or close to it. At the other extreme, there are firms with large unused loss carryforwards which pay no immediate taxes. An extra dollar of interest paid by these firms would create only a potential future deduction, usable when and if the firm earns enough to work off prior carryforwards. The expected realizable tax shield is positive but small. Also, there are firms paying taxes today which cannot be sure they will do so in the future. Such a firm values expected future interest tax shields at somewhere between zero and the full statutory rate. In the "corrected" MM theo ry [28] any tax-paying corporation gains by borrowing; the greater the marginal tax rate, the greater the gain. This gives the top line in the figure. In Miller's theory, the personal income taxes on interest payments would exactly offset the corporate interest tax shield, provided that the firm pays the full statutory : ax rate. However, any firm paying a lower rate would see a net loss to corporate borrowing and a net gain to lending. This gives the bottom line.

There are also compromise theories, advanced by $D^{\prime}$ Angelo and Masulis [12], Modigliani [30] and others, indicated by : he middle dashed ine in the 
figure. The compromise theories are appealing because they seem less extreme than either the MM or Miller theories. But regardless of which theoryholds, the slope of the line is always positive. The difference between (1) the tax advantage of borrowing to firms facing the full statutory rate, and (2) the tax advantage of lending (or at least not borrowing) to firms with large tax loss carryforwards, is exactly the same as in the "extreme" theories. Thus, although the theories tell different storles abalt aggregate supply and demand of corporate debt, they make essentially the same predictions about which firms borrow more or less than average.

So the tax side of the static tradeoff theory predicts that IBM should borrow more than Bethlehem Steel, other things equal, and that General Motors' debt-to-value ratio should be more than Chrysler's.

Costs of financial distress. Costs of financial distress include the legal and administrative costs of bankruptcy, as well as the subtler agency, moral hazard, monitoring and contracting costs which can erode firm value even if formal default is avoided. We know these costs exist, although we may debate their magnitude. For example, there is no satisfactory explanation of debt covenants unless agency costs and moral hazard problems are recognized.

The 1iterature on costs of financial distress supports two qual itative statements about financing behavior. 6

1. Risky firms a ght to borrow less, other things equa 1 . Here "risk" would be defined as the variance rate of the market value of the firm's assets. The higher the variance rate, the greater the probability of default on any given package of debt claims. Since costs of financial distress are caused by threatened or actur 1 default, safe firms as ght to 
be able to borrow more before expected costs of financial distress offset the tax advantages of borrowing.

2. Firms holding tangible assets-in-place having active second-hand markets will borrow less than firms holding specialized, intangible assets or valuable growth opportunities. The expected cost of financial distress depends not just on the probability of trouble, but the value lost if tras ble comes. Specialized, intangible assets or growth opportunities are more likely to lose value in financial distress.

The Pecking Order Theory

Contrast the static tradeoff theory with a competing popular story based on a financing pecking order:

1. Firms prefer internal finance.

2. They adapt their target dividend payout ratios to their investment opportunities, althaigh dividends are sticky and target payout ratios are only gradually adjusted to shifts in the extent of valuable investment opportunities.

3. Sticky dividend policies, plus unpredictable fluctutions in profitability and investment opportunities, mean that internally-generated cash flow may be more or less than investment astlays. If it is less, the firm first draws down its cash balance or marketable securities portfolio.

4. If external finance is required, firms issue the safest security first. That is, they start with debt, then possibly hybrid securities such as convertible bonds, then perhaps equity as a 1 ast resort. In this story, there is no well-defined target debt-equity mix, because 
there are two kinds of equity, internal and external, one at the top of the pecking order and one at the bottom. Each firm's observed debt ratio reflects its cumulative requirements for external finance.

The pecking order 11terature. The pecking order hypothesis is hardly new. 8 For example, it comes through loud and clear in Donaldson's 1961 study of the financing practices of a sample of large corporations. He observed [13, p. 67] that "Management strongly favored internal generation as a source of new funds even to the exclusion of external funds except for occasional unavoidable 'bulges' in the need for funds." These bulges were not generally met by cutting dividends: Reducing "the customary cash dividend payment ... was unthinkable to most managements except as a defensive measure in a period of extreme financial distress." (p. 70) Given that external finance was needed, managers rarely thas ght of issuing stock:

Though few companies would go so far as to rule out a sale of common under any circumstances, the large majority had not had such a sale in the past 20 years and did not anticipate one in the foreseeable future. This was particularly remarkable in view of the very high Price-Earnings ratios of recent years. Several financial officers showed that they were well aware that this had been a good time to sell common, but the reluctance still persisted. (p. 57-58)

of carse, the pecking order hypothesis can be quickly rejected if we require it to explain everything. There are plenty of examples of firms issuing stock when they could issue investment-grade debt. But when one looks at aggregates, the heavy reliance on internal finance and debt is clear. For all non-financial corporations over the decade 1973-1982, internally generated cash covered, on average, 62 percent of capital expenditures, including investment in inventory and other current assets. The bulk of required external financing came from borrowing. Net new stock issues were never more 
than 6 percent of external financing. 9 Anyone innocent of modern finance who looked at these statistics wald find the pecking order idea entirely plausible, at least as a description of $t$ ypical behavior.

Writers on "managerial capitalism" have interpreted firm's rellance on internal finance as a byproduct of the separation of ownership and control: professional managers avoid relying on external finance because it would subject them to the discipline of the capital market. ${ }^{10}$ Donaldson's books was not primarily about managerial capital ism, but he nevertheless observed that the financing decisions of the firms he studied were not directed towards maximizing shareholder wealth, and that scholars attempting to explain those decisions would have to start by recognizing the "managerial view" of corporate finance. [14, Ch. 2]

This conclusion is natural given the state of finance theory in the 1960s. Today, it is not so obvious that financing by a pecking order goes against shareholders' interests.

External financing with asymmetric information. I used to ignore the pecking order story because I could think of no theoretical foundation for it that would fit in with the theory of modern finance. An argument cal $1 d$ be made for internal financing to avoid issue costs, and if external finance is needed, for debt to avoid the still higher issue costs of equity. But issue costs in themselves do not seem large enough to override the costs and benefits of leverage emphasized in the static tradeoff story. However, recent work based on asymmetric information gives predictions roughly in line with the pecking order theory. The following brief exposition is based on a forthcoming joint paper by me and Nicholas Majluf [34], although I will here boil down that paper's argument to absolute essentials. 
Suppose the firm has to raise $N$ dollars in order to undertake some potentially valuable investment opportunity. Let $y$ be this opportunity's net present value (NPV) and $x$ be what the firm will be worth if the opportunity is passed by. The firm's manager knows what $x$ and $y$ are, but investors in capital markets do not: they see only a joint distribution of possible values $(\tilde{x}, \tilde{y})$. The information asymmetry is taken as given. Aside from the information asymmetry, capital markets are perfect and semi-strong form efficient. MM's Proposition I holds in the sense that the stock of debt relative to real assets is irrelevant if information available to investors is held constant.

The benefit to raising $N$ dollars by a security issue is $y$, the NPV of the firm's investment opportunity. There is also a possible cost: the firm may have to sell the securities for less than they are really worth. Suppose the firm issues stock with an aggregate market value value, when issued, of N. (I will consider debt issues in a moment.) However, the manager knows the shares are really worth $N_{1}$. That $1 s, N_{1}$ is what the new shares will be worth, other things equal, when investors acquire the manager's special knowledge.

Majluf and I discuss several possible objectives managers might pursue in this situation. The one we think makes the most sense is maximizing the "true," or "Intrinsic" val ue of the firm's existing shares. That is, the manager worrles about the value of the "old" shareholders' stake in the firm. Moreo ver, investors know the manager will do this. In particular, the "new" investors who purchase any stock issue will assume that the manager is not on their side, and will rationally adj ust the price they are willing to pay. Define $\Delta N$ as the amount by which the shares are over- or undervalued: 
$\Delta N \equiv N_{1}-N$. Then the manager will issue and invest when

$$
\mathrm{y} \geq \Delta \mathrm{N} \quad \text {. }
$$

If the manager's inside information is unfavorable, $\Delta N$ is negative and the firm will always issue, even the only good use for the funds raised is to put them in the bank--a zero-NPV investment. ${ }^{11}$ If the inside information is favorable, however, the firm may pass up a positive-NPV investment opportunity rather than issue undervalued shares.

But if management acts this way, its decision to issue will signal bad news to both old and new shareholders. Let $V$ be the market value of firm (price per share times number of shares) it does not issue, and $V^{\prime}$ be market value if it does issue; $V^{\prime}$ includes the value of the newly-issued shares. Thus, if everyone knows that managers will act according to Inequ lity (1), the conditions for a rational expectations equilibrium are $:^{12}$

$$
\begin{gathered}
V=E(\tilde{x} \mid \text { no issue })=E(\tilde{x} \mid y \leq \Delta N) \\
V^{\prime}=E(\tilde{x}+\tilde{y}+N \mid \text { issue })=E(\tilde{x}+\tilde{y}+N \mid y \geq \Delta N) .
\end{gathered}
$$

The total dollar amount raised is fixed by assumption, but the number of new shares needed to raise that amount is not. Thus $\Delta N$ is endogenous: it depends on $V^{\prime}$. For example, if the firm issues, the fraction of all shares held by "new" stockholders is $\mathrm{N} / \mathrm{V}^{\prime}$. The manager sees the true value of their claim as:

$$
N_{1}=\frac{N}{V^{\prime}}(x+y+N)
$$

Thus, given $N, x$ and $y$, and given that stock is issued, the greater the price per share, the less value is given up to new stockholders, and the less $\Delta \mathrm{N}$ is. 
Majluf and I have discussed the assumptions and implications of this model in considerable detail. But here are the two key points:

1. The cost of relying on external financing. We usually think of the cost of external finance as administrative and underwriting costs, and in some cases underpricing of the new securities. Asymmetric information creates the possibility of a different sort of cost: the possibility that the firm will choose not to issue, and will therefore pass up a positive-NPV investment. This cost is avoided if the firm can retain enough internal $l y$-generated cash to cover its positive-NPV opportunities.

2. The advantages of debt over equity issues. If the firm does seek external funds, it is better off issuing debt than equity securities. The general rule is, "Issue safe securities before risky ones."

This second point is worth explaining further. Remember that the firm issues and invests if $y$, the NPV of its investment opportunity, is greater than or equal to $\Delta N$, the amount by which the new shares are undervalued (if $\Delta N>0$ ) or overvalued (if $\Delta N<0$ ). For example, suppose the investment requires $N=\$ 10$ million, but in order to raise that amount the firm must issue shares that are really worth $\$ 12$ million. It will go ahead only if project NPV is at least $\$ 2$ million. If it is worth only $\$ 1.5$ million, the firm refuses to raise the money for it; the intrinsic overall val ue of the firm is reduced by $\$ 1.5$ million, but the old shareholders are $\$ 0.5$ million better off.

The manager could have avolded this problem by building up the firm's cash reserves--but that is hindsight. The only thing he can do now is to redesign the security issue to reduce $\Delta N$. For example, if $\Delta N$ could be cut to $\$ 0.5$ million, the investment project could be financed without diluting the 
true value of existing shares. The way to reduce $\Delta N$ is to issue the safest possible securities--strictly speaking, securities whose future value changes least when the manager's inside information is revealed to the market.

of course, $\Delta N$ is endogenars, so it is loose talk to speak of the manager controlling it. However, there are reasonable cases in which the absolute value of $\Delta \mathrm{N}$ is always less for debt than for equity. For example, if the firm can issue default-risk free debt, $\Delta N$ is zero, and the firm never passes up a valuable investment opportunity. Thus, the ability to issue default-risk free debt is as good as cash in the bank. Even if default risk is introduced, the absolute value of $\Delta \mathrm{N}$ will be less for debt than for equit $y$ if we the customary assumptions of option pricing models. ${ }^{13}$. Thus, if the manager has favorable information $(\Delta N>0)$, it is better to issue debt than equity.

This example assumes that new shares or risky debt wal ld be underpriced. What if the managers' inside information is unfavorable, so that any risky security issue would be overpriced? In this case, wal $1 \mathrm{dn}$ 't the firm want to make $\Delta N$ as large as possible, to take maximum advantage of new investors? If so, stock would seem better than debt (and warrants better st111). The decision rule seems to be, "Issue debt when investors undervalue the firm, and equity, or some other risky security, when they overval ue it.

The trouble with this strategy is obvious once you put yourself in investors' shoes. If yal know the firm will issue equity only when it is overpriced, and debt otherwise, you will refuse to buy equit y unless the firm has already exhausted its "debt capacity"--that is, unless the firm has issued so much debt already that it would face substantial additional costs in 
issuing more. Thus investors would effectively force the firm to follow a pecking order.

Now this is clearly too extreme. The model just presented wan ld need lots of fleshing out before it could fully capture actual behavior. I have presented it just to show how models based on asymmetric information can predict the two central ideas of the pecking order story: first, the preference for internal finance, and, second, the preference for debt over equity if external financing is sought.

What We Know About Corporate Financing Behavior

I will now list what we know about financing behavior and try : 0 make sense of this knowledge in terms of the two hypotheses sketched above. I begin with five facts about financing behavior, and then offer a few generalizations from weaker statistical evidence or personal observation. of caurse even "facts" based on apparently good statistics have been known to melt away under further examination, so read with caution.

Internal vs. external equity. Aggregate investment as tlays are predominantly financed by debt issues and internally-generated funds. New stock issues play a relatively small part. Moreover, as Donaldson has observed, this is what many managers say they are trying to do.

This fact is what suggested the pecking order hypothesis in the first place. However, it might also be explained in a static tradeoff theory by adding significant transaction costs of equity issues and noting the favorable tax treatment of capital gains relative to dividends. This would make external equity relatively expensive. It would explain why companies keep 
target dividend payouts low enough to avold having to make regular stock issues. ${ }^{14}$ It would also explain why a firm whose debt ratio soars above target does not immediately issue stock, buy back debt, and re-establish a more moderate debt-to-val ue ratio. Thus firms might take extended excursions above their debt targets. (Note, however, that the static tradeoff hypothesis as usua $11 y$ presented rarely mentions this kind of adj ustment cost.)

But the out-of-pocket costs of repurchasing shares seem fairly small. It is thus hard to explain extended excursions below a firm's debt target by an augmented static tradeoff theory--the firm could quickly issue debt and buy back shares. Moreover, if personal income taxes are important in explaining firms' apparent preferences for internal equit $y$, then it's difficult to explain why external equity is not strongly negative--that is, why most firms haven't gradually moved to materlally lower target payout ratios and used the released cash to repurchase shares.

Timing of security issues. Firms apparently : ry $=0$ "time" stock issues when securit y prices are "high." Given that they seek external finance, they are more likely : o issue stock (rather than debt) after stock prices have risen than after they have fallen. For example, past stock price movements were one of the best-performing variables in Marsh's study [21] of British firms' choices between new debt and new equity issues. Taggart [39] and others ${ }^{15}$ have found similar behavior in the United States.

This fact is embarassing to static tradeoff advocates. If firm value rises, the debt-to-val ue ratio falls, and firms ought to issue debt, not equic $y$, to rebalance their capital structures.

The fact is equally embarrassing to the pecking order hypothesis. There is no reason to believe that the manager's inside information is 
systematically more favorable when stock prices are "high." Even if there were such a tendenc/, investors would have learned it by now, and would interpret the firm's issue decision accordingly. There is no way firms can systematically take advantage of purchasers of new equity in a rational expectations equilibrium.

Borrowing against intangibles and growth opportunities. Firms holding valuable intangible assets or growth opportunities tend to borrow less than firms holding mostly : angible assets. For example, Long and Mal itz [20] faund a significant negative relationship between rates of investment in advertising and research and development (R\&D) and the level of borrowing. They also found a significant positive relationship between the rate of capital expenditure (in fixed plant and equipment) and the level of borrowing.

Williamson [14] reached the same conclusion by a different route. His proxy for a firm's intanglbles and growth opportunities was the difference between the market value of its debt and equity securities and the replacement cost of its tangible assets. The higher this proxy, he found, the less the firm's debt-to-value ratio.

There is plenty of indirect evidence indicating that the level of borrowing is determined not just by the value and risk of the firm's assets, but al so by : he type of assets it holds. For example, without this distinction, the static tradeoff theory would specify all target debt ratios in terms of market, not book val ues. Since many firms have market val ues far in excess of book values (even if those book values are restated in current dollars), we ought to see at least a few such firms operating comfortably at very high book debt ratios-and of course we do not. This fact begins to make sense, however, as soon as we real ize that book val ues reflect assets-in-place 
(tangible assets and working capital). Market values reflect intangibles and growth opportunities as well as assets-in-place. Thus, firms do not set target book debt ratios because accountants certify the books. Book asset values are proxies for the values of assets in place. 16

Exchange offers. Masulis $[22,23]$ has shown that stock prices rise, on average, when a firm offers to exchange debt for equity, and fall when they offer to exchange equity for debt. This fact car ld be explained in varias ways. For example, it might be a tax effect. If most firms' debt ratios are below their optimal ratios (1.e., to the left of the optimum in Figure 1), and if corporate interest tax shields have significant positive value, then debt-for-equity exchanges would tend to move firms closer to optimum capital structure. Equity-for-debt swaps would tend to move them farther away.

The evidence on exchanges hardly bullds confidence in the static tradeoff theory as a description of financing behavior. If the theory were right, firms wa ld be sometimes above, and sometimes below, their optimum ratios. Those above would offer to exchange equit $y$ for debt. Those below would offer debt for equity. In both cases, the firm would move closer to the optimum. Why should an exchange offer be good news if in one direction and bad news if in the $o$ ther?

As Masulis points out, the firm's willingness to exchange debt for equity might signal that the firm's debt capacity had, in management's opinion, increased. That is, it wa ld signal an increase in firm value or a reduction in firm risk. Thus, a debt-for-equity exchange would be good news, and the opposite exchange bad news.

This "information effect" explanation for exchange offers is surely right in one sense. Any time an announcement affects stock price, we can infer that 
the announcement conveyed information. That is not much help except to prove that managers have some information investors do not have.

The idea that an exchange offer reveals a change in the firm's target debt ratio, and thereby signals changes in firm val ue or risk, sou nds plausible. But an equally plausible story can be told without saying anything about a target debt ratio. If the manager with superior information acts to maximize the Intrinsic value of existing shares, then the announcement of a stock issue sha ld be bad news, other things equal, because stock issues will be more likely when the manager receives bad news. ${ }^{17}$ on the other hand, stock retirements should be good news. The news in both cases has no evident necessary connection with shifts in target debt ratios.

It may be possible to build a model combining asymetric information with the costs and benefits of borrowing emphasized in static tradeoff stories. My guess, however, is that $1 \mathrm{t}$ will prove difficult to do this without al so introducing some elements of the pecking order story.

Issue or repurchase of shares. The fifth fact is no surprise given the fourth. On average, stock price falls when firms announce a stock issue. Stock prices rise, on average, when a stock repurchase is announced. Th1s fact has been confirmed in several studies, including those by Korwar [18], Asquith and Mullins [2], Dann and Mikkleson [10], Vermaelen [40], and DeAnge10, DeAngelo and Rice [11].

This fact is again hard to explain by a static tradeoff model, except as an information effect in which stock issues or retirements signal changes in the firm's target debt ratio. I've al ready commented on that.

The simple asymmetric information model I used to motivate the pecking order hypothesis does predict that the announcement of a stock issue will 
cause stock price to fall. It also predicts that stock price sha ld not fall, other things equal, if default-risk debt is issued. Of course, no private company can issue debt that is absolutely protected from default, but it seems reasonable to predict that the average stock price impact of high-grade debt issues will be small relative to the average impact of stock issues. This is what Dann and Mikkleson [10] find.

These results may make one a bit more comfortable with asymmetric information models of the kind sketched above, and thus a bit more comfortable with the pecking order story.

That's the five facts. Here now are three items that do not qualify for that list--just call then "observations."

Existence of target ratios. Marsh [21] and Taggart [39] have fau nd some evidence that firms adjust towards a target debt-to-value ratio. However, a model based solely on this partial adjustment process would have a very low $\mathrm{R}^{2}$. Apparently = he static tradeoff model captures only a small part of actual behavior. 18

Risk. Risky firms tend to borrow less, other things equa 1. For example, both Long and Malitz [20] and Williamson [41] found significant negative relationships between unlevered betas and the level of borrowing. However, the evidence on risk and debt policy is not extensive enough to be totally convincing.

Taxes. I know of no study clearly demonstrating that a firm's tax status has predictable, material effects. on its debt policy. ${ }^{19}$ I think the wait for such a study will be protracted.

Admittedly it's hard to classify firms by $t$ ax status without implicitly classifying them on other dimensions as well. For example, firms with large 
tax loss carryforwards may also be firms in financial distress, which have high debt ratios almost by definition. Firms with high operating profitability, and therefore plenty of unshielded income, may also have valu ble intangible assets and growth opportunities. Do they end up with a higher or lower than average debt-to-value ratio? Hard to say.

\section{Conclusion}

People feel comfortable with the static tradeoff story because it soinds plausible and yields an interior optimum debt ratio. It rationalizes "moderate" borrowing.

Well, the story may be moderate and plausible, but that does not make it right. We have to ask whether it explains firms' financing behavior. If it does, fine. If it does not, then we need a better theory before offering advice to managers.

The static tradeoff story works to some extent, but it seems to have an unacceptably low $\mathrm{R}^{2}$. Actual debt ratios vary widely across apparently similar firms. Either firms take extended excursions from their targets, or the targets themselves depend on factors not yet recognized or understood.

At this point we face a tactical choice between two research strategies. First, we cald try : o expand the static tradesf story by introducing adjustment costs, possibly including those stemming from asymmetric Information and agenc problems. Second, we calld start with a story based on asymmetric information, and expand it by adding only those elements of the static tradeoff which have clear empirical support. I think we will progress farther faster by the latter route. 
Here is what I really think is going on. I warn you that the following "modified pecking order" story is grossly oversimplified and underqua lified. But I think it is generally consistent with the empirical evidence.

1. Firms have good reasons to avoid having to finance real investment by issuing common stock or other risky securities. They do not want to run the risk of falling into the dilemma of either passing by positive-NPV projects or issuing stock at a price they think is too low.

2. They set target dividend payout ratios so that normal rates of equit y investment can be met by internally generated funds.

3. The firm may al so plan to cover part of normal investment astlays with new borrowing, but it tries to restrain itself enough to keep the debt safe--that is, reasonably close to default-risk free. It restrains itself for two reasons: first, to avoid any material costs of financial distress; and second, to maintain financial slack in the form of reserve borrowing power. "Reserve borrowing power" means that it can issue safe debt if it needs to.

4. Since target dividend payout ratios are sticky, and investment opportunities fluctuate relative to internal cash flow, the firm will from time to time exhaust its ability : o issue safe debt. When this happens, the firm turns to less risky securities first--for example, risky debt or convertibles before common stock.

The crucial difference between this and the static tradeoff story is that, in the modified pecking order story, observed debt ratios will reflect the cumulative requirement for external financing--a requirement cumulated over an extended period. ${ }^{20}$ For example, think of an unusually profitable firm in an industry generating relatively slow growth. That firm will end up with 
an unusually low debt ratio compared to its industry's average, and 1t won't do much of any= hing about 1t. It won't go out of its way to issue debt and retire equity to achieve a more normal debt ratio.

An unprofitable firm in the same industry will end up with a relatively high debt ratio. If it is high enough to create significant costs of financial distress, the firm may rebal ance its capital structure by issuing equi: y. On the other hand, it may not. The same asymmetric information problems which sometimes prevent a firm from issulng stock to finance real investment will sometimes also block issuing stock to retire debt. 21

If this story is right, average debt ratios will vary from industry to industry, beca use asset risk, asse: =ype, and requirements for external funds also vary by industry. But a long-run industry average will not be a meaningful target for individual firms in that industry.

Let me wrap this up by noting the two clear gaps in my description of "what is really going on." First, the modifled pecking order story depends on sticky dividends, but does not explain why : he are sticky. Second, it leaves us with at best a fuzzy understanding of when and why firms issue common equity. Unfortunately I have nothing to say on the first weakness, and only the following brief comments on the second.

The modified pecking order story recognizes both asymmetric information and costs of financial distress. Thus the firm faces two increasing costs as it climbs up the pecking order: it faces higher odds of incurring costs of financial distress, and also higher odds that future positive-NPV projects will be passed by because the firm will be unwilling to finance them by issuing common stock or other risky securities. The firm mal choose to reduce 
these costs by issuing stock now even if new equit $y$ is not needed immediately to finance real investment, just to move the firm down the pecking order. In other words, financial slack (liquid assets or reserve borrowing power) is valuable, and the firm may rationally issue stock to acquire it. (I say "may" beca use the firm which issues equi- y to buy financial slack faces the same asymmetric information problems as a firm issuing equity to finance real investment.) The optimal dynamic issue strategy for the firm under asymmetric information is, as far as I know, totally unexplored territory. 22 
FOOTNOTES

*Sloan School of Management, MIT, and National Bureau of Economic Research.

1. The finance and economics literature has at least three "managerial" strands: (1) descriptions of managerial capitalism, in which the separation of ownership and control is taken as a central fact of life, for example Berle and Means [5]; (2) agenct theory, pioneered for finance by Jensen and Meckling [17], and (3) the detailed analysis of the personal risks and rewards facing managers and how their responses affect firms' financing or investment choices. For examples of Strand (3), see Ross's articles on financial signalling $[36,37]$.

2. Put forward in "Debt and Taxes," [26], esp. pp. 272-273. Note that Miller did not claim that all of firms' financing habits are neutral mutations, only that some of them may be. I doubt that Miller intended this idea as a strict null hypothesis (see below).

3. The only early cross-sectional study I know of which sidesteps these issues is MM's 1966 paper on the cost of capital for the electric utility industry [28]. Their "corrected" theory says that firm value is independent of capital structure except for the val ue added by the present value of interest tax shields. Thus tax-paying firms would be expected to substitute debt for equity, at least up to the point where the probability of financial distress starts to be important. However, the regulated firms MM examined had little tax incentive to use debt, because their interest tax shields were passed through to consumers. If a regulated firm pays an extra one dollar of interest, and thus saves $T_{c}$ in corporate income taxes, regulators are supposed to reduce the firm's 
pre-tax operating income by $T_{c} /\left(1-T_{c}\right)$, the grossed-up value of the tax saving. This roughly cancels out any tax advantage of borrowing. Thus regulated firms should have little incentive to borrow enaigh to flirt with financial distress, and their debt ratios could be dispersed across a conservative range.

Moreover, MM's test could pick up the present value of interest tax shields provided they adjusted for differences in operating income. Remember, interest tax shields are not eliminated by regulation, just offset by reductions in allowed operating income.

Thus regulated firms are relatively good subjects for cross-sectional tests of static tradeoff theorles. MM's theory seemed to work fairly well for three years in the mid-1950s. Unfortunately, MM's equ tions didn't give sensible coefficients when fitted on later data (see for example, Robichek, McDonald and Higgins [35]). There has been little further work attempting to extend or adapt MM's 1966 model. In the meantime, theory has moved on.

4. Although Miller's "Debt and Taxes" model [26] was a major conceptu 1 step forward, I do not consider it an adequate description of how taxes affect optimum capital structure or expected rates of return on debt and equit y securities. See Gordon and Malkiel [16] for a recent review of the evidence.

5. Cordes and Scheffrin [8] present evidence on the cross-sectional dispersion of effective corporate tax rates.

6. I have discussed these two points in more detail in [32 and 33]. 
7. If it is more, the firm first pays off debt or invests in cash or marketable securities. If the surplus persists, it may gradual $l y$ increase its target payout ratio.

8. Although I have not seen the term "pecking order" used before.

9. These figures were computed from Brealey and Myers [7], Table 14-3, p. 291.

10. For example, see Berle [4], or Berle and Means [5].

11. If the firm always has a zero-NPV opportunity available to 1t, the distrbution of $\tilde{y}$ is truncated at $\tilde{y}=0$. I al so assume that $\tilde{x}$ is non-negative.

12. The simple model embodied in (1) and (2) is a direct descendant of Akerlof's work [1]. He investigated how markets can fail when buyers can not verify the qua lity of what they are offered. Faced with the risk of buying a lemon, the buyer will demand a discount, which in turn discar rages the potential sellers who do not have lemons. However, in Majluf's and my model, the seller is offering not a single good, but a partial claim on two, the investment project (worth $y$ ) and the firm without the project (worth $x$ ). The information asymmetry applies to both goods--for example, the manager may recelve inside information that amounts to good news about $x$ and bad news about $y$, or vice versa, or good or bad news abas t both.

Moreover, the firm may suffer by not selling stock, because the investment opportunit $y$ is lost. Management will sometimes issue even when the stock is undervalued by investors. Consequently, investors on the other side of the transaction do not automatically interpret every stock issue as an attempted ripoff--if they, did stock was ld never be issued in a rational expectations equilibrium. 
13. This amounts to assuming that changes in firm value are lognormally distributed, that managers and investors agree on the variance rate, and that managers know the current value of $\tilde{x}+\tilde{y}$ but investors do not. If there is asymmetric information about the variance rate, but not about firm value at the time of issue, the pecking order calld be reversed. See Giammarino and Neave [15].

14. Regulated firms, particularly electric utilities, typically pay dividends generous enough to force regular trips to the equity market. They have a special reason for this polic : it improves their bargaining position vs. consumers and regulators. It turns the opportunity cost of capital into cash requirements.

15. Jalilvand and Harris [16], for example.

16. The problem is not that intangibles and growth opportunities are risky. The securities of growth firms may be excellent collateral. But the firm which borrows against intangibles or growth opportunities may end up reducing their value.

17. This follows from the simple model presented above. See Myers and Majluf [34] for a formal proof.

18. Of course, we could give each firm its own target, and leave that target free to wander over time. But then we would explain everything and know nothing. We want a the ry which predicts how debt ratios vary across firms and time.

19. For example, both Williamson [41] and Long and Malitz [20] introduced proxies for firms' tax status, but falled to find any significant, independent effect on debt ratios. 
20. The length of that period reflects the time required to make a significant shift in a target dividend payaut ratio.

21. The factors that make financial distress costly also make it difficult to escape. The gain in firm value from rebal ancing is highest when the firm has gotten into deep trouble and lenders have absorbed a significant capital loss. In that case, rebalancing gives lenders a windfall gain. This is why firms in financial distress often do not rebal ance their capital structures.

22. If the information assymetry disappears from time to time, then the firm clearly should stock up with equity before it reappears. This observation is probably not much practical help, however, because we lack an objective proxy for changes in the degree of asymetry. 


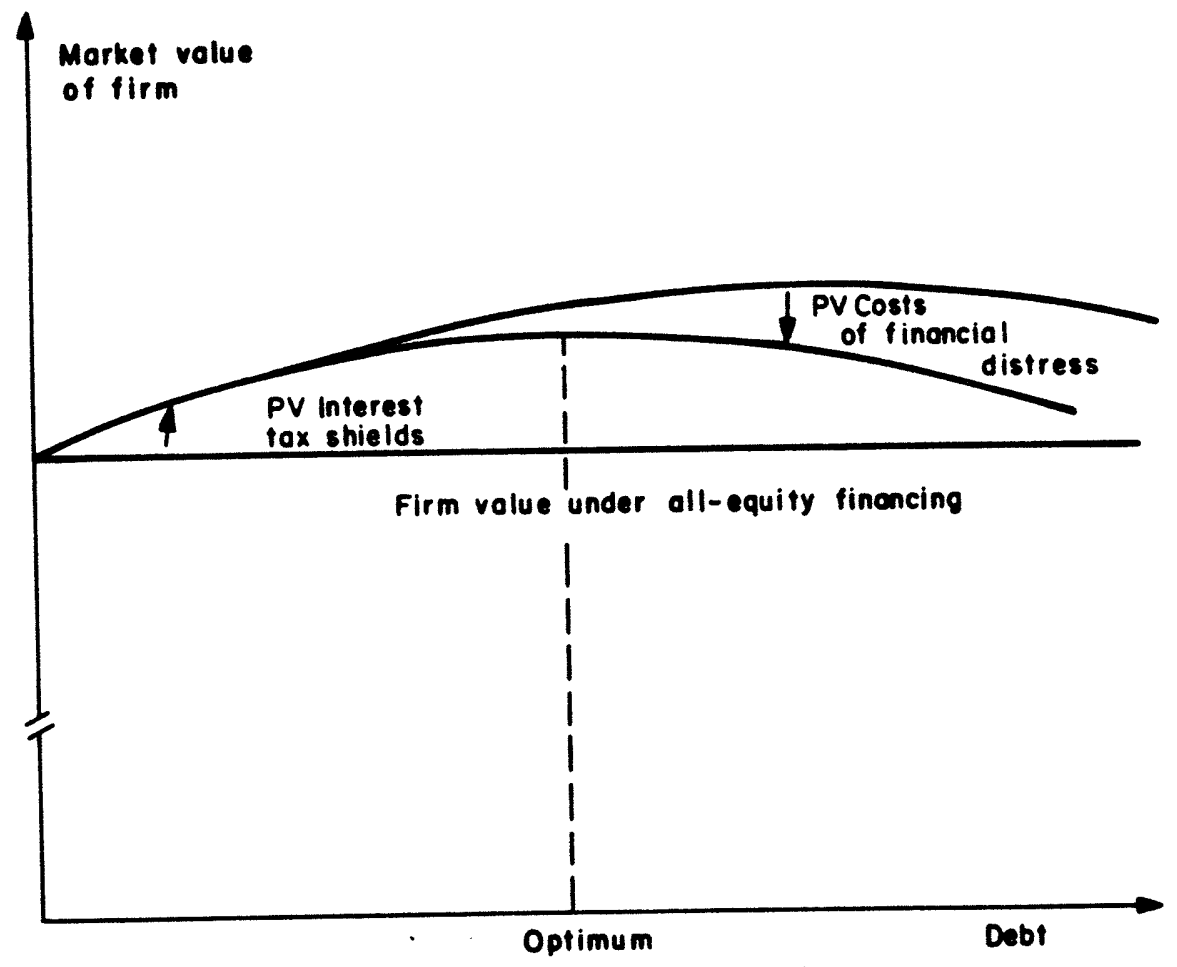

Figure 1. The static-tradeoff theory of capital structure.

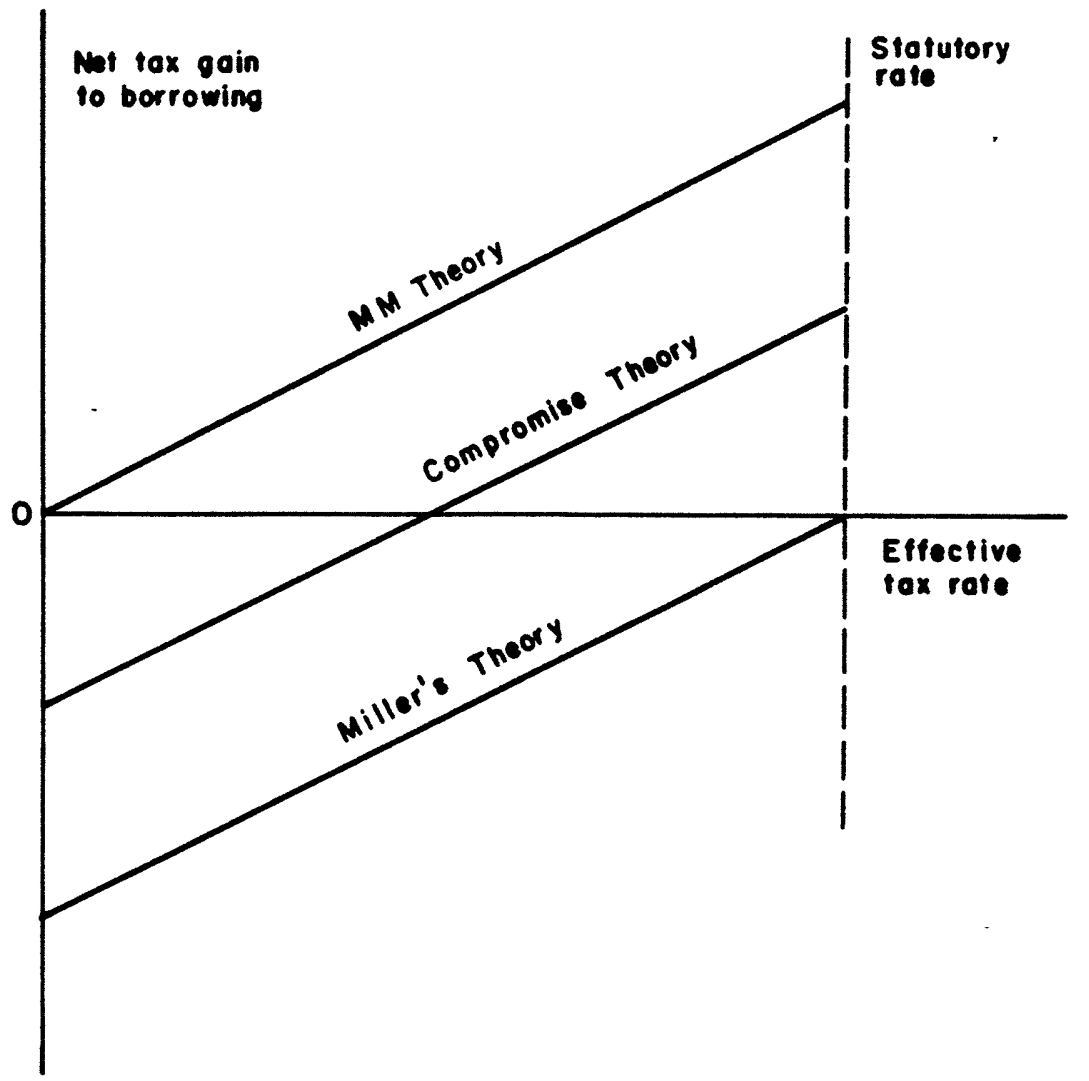

Figure 2. The net tax gain to corporate borrowing. 
REFERENCES

Akerlof, G.A., "The Market for 'Lemons:' Qu lity and the Market Mechanism," Quarterly Journal of Economics, 84 (August 1970), 488-500.

Asquith, P. and D.W. Mullins, "Equity Issues and Stock Price Dilution," Working Paper, Harvard Business School, May 1983.

Barges, A., The Effect of Capital Structure on the Cost of Capital, Prentice-Hall, Inc., Englewood Cliffs, N.J., 1963.

Berle, A., The 20th Century Capital ist Revolution, Harcourt, Brace and World, Inc. $19 \overline{54}$

Berle, A. and G. Means, The Modern Corporation and Private Property, MacMillan, New York, 1932.

Black, F., "The Dividend Puzzle," Jaurnal of Portfollo Management, 2 (Winter 1976), 5-8.

Brealey, R.A. and S.C. Myers, Principles of Corporate Finance, 2nd Ed., McGraw-Hill Book Co., New York, 1984.

Cordes, J.J. and S.M. Sheffrin, "Estimating the Tax Advantage of Corporate Debt," Journal of Finance, 38 (March 1983), 95-105.

Dann, L.Y., "Common Stock Repurchases: An Analysis of Returns to Bondholders and Stockholders," Journal of Flnanclal Economics, 9 (June 1981), 113-138.

Dann, L.Y. and W.H. Mikkleson, "Convertible Debt Issun nce, Capital Structure Change and Financing-Related Information: Some New Evidence," Working Paper, Amos Tuck School of Business Administration, 1983.

DeAngelo, H., L. DeAngelo, and E.M. Rice, "Minorit y Freezeouts and Stockholder Wealth," Working Paper, Gradu te School of Business Administration, Universi: y of Washington, 1982.

DeAngelo, H., and R. Masulis, "Optimal Capital Structure Under Corporate and Personal Taxation," Journal of Financlal Economics, 8 (March 1980), 3-29.

Donaldson, G., Corporate Debt Capac1ty: A Study of Corporate Debt Pollo and the Determination of Corporate Debt Capacity, Boston, Division of Research, Harvard Graduate School of Business Administration, 1961.

Donaldson, G., Strategy for Financial Mobility, Boston, Division of Research, Harvard Graduate School of Business Administration, 1969. 
Giammarino, R.M. and E.H. Neave, "The Failure of Financial Contracts and the Relevance of Financial Policy," Working Paper, Queens University, 1982.

Gordon, R.H. and G.B. Malkiel, "Corporation Finance," in H.J. Aaron and J.A. Pechman, How Taxes Affect Economic Behavior, Brookings Institution, Washington, DC, 1981 .

Jal Ilvand, A. and R.S.. Harris, "Corporate Behavior in Adjusting to Capital Structure and Dividend Policy: An Econometric Study," Journal of Finance, 39 (March 1984), 127-145.

Jensen, M. C. and W. Meckling, "Theo ry of the Firm: Managerial Behavior, Agency Costs and Capital Structure," Journal of Financial Economics, 3 (October 1976), 11-25.

Korwar, A.N., "The Effect of New Issues of Equity: An Empirical Exami nation," Working Paper, University of California, Los Angeles, 1981.

Lintner, J. "Distribution of Incomes of Corporations Among Dividends, Retained Earnings and Taxes," American Economic Review, 46 (May 1956), 97-113.

Long, M.S., and E.B. Malitz, "Investment Patterns and Financial Leverage," Working Paper, National Bureau of Economic Research, 1983.

Marsh, P.R., "The Choice Between Equity and Debt: An Empirical Study," Journal of Finance, 37 (March 1982), 121-144.

Masulis, R.W., "The Effects of Capital Structure Change on Security Prices: A Study of Exchange Offers," Journal of Financial Economics, 8 (June 1980), 139-177.

Masulis, R.W., "The Impact of Capital Structure Change on Firm Value," Journal of Finance, 38 (March 1983), 107-126.

Mikkelson, W.H., "Capital Structure Change and Decreases in Stockholders' Wealth: A Cross-Sectional Study of Convertible Security Calls," Forthcoming in B. Friedman, Ed., Corporate Capital Structures in the United States, (National Bureau of Economic Research Conference Volume).

Mikkelson, W.H., "Convertible Calls and Security Returns," Journal of Financial Economics, 9 (June 1981), 113-138.

Miller, M., "Debt and Taxes," Journal of Finance, 32 (May 1977), 261-275.

Miller, M, and F. Modigliani, "Dividend Polley, Growth and the Valuation of Shares," Journal of Business, 34 (October 1961), 411-433.

Miller, M.H. and F. Modiglianl, "Some Estimates of the Cost of Capital to the Electric Ut1lit y Industry, 1954-1957," American Economic Review, 56 (June 1966), 333-391. 
Miller, M.H. and K. Rock, "Dividend Policy Under Information Asymmetry," Working Paper, Gradu te School of Business, University of Chicago, November 1982 .

Modigliani, F., "Debt, Dividend Polict, Taxes, Inflation and Market Valuation," Journal of Finance, 37 (May 1982), 255-273.

Modigliani, F. and M. Miller, "The Cost of Capital, Corporation Finance and the Theory of Investment," American Economic Review, 53 (June 1958), 261-297.

Myers, S., "Determinants of Corporate Borrowing," Journal of Financial Economics, 5 (November 1977), 147-176.

Myers, S., "The Search for Optimal Capital Structure," Midland Corporate Finance Journal, 1 (Spring 1984), 6-16.

Myers, S., and N. Majluf, "Corporate Financing and Investment Decisions When Firms Have Information Investors Do Not Have," Journal of Financial Economics, forthcoming.

Robicheck, A.A., J. MacDonald and R. Higgins, "Some Estimates of the Cost of Capital to the Electric Utility Industry, 1954-1954: Comment," American Economi c Review, 57 (D ecember 1967), 1278-1288.

Ross, S.A., "Some Notes on Financial-Incentive Signalling Models, Activity Choice and Risk Preferences," Journal of Finance, 33 (June 1978), 777-792.

Ross, S.A., "The Determination of Financial Structure: The Incentive-Signal l ing Approach," Bell Jal rnal of Economics, 8 (Spring 1977), 23-40.

Smith, C. and Warner, J., "On Financial Contracting: An Analysis of Bond Covenants," Journal of Financial Economics, 7 (June 1979), 117-161.

Taggart, R., "A Model of Corporate Financing Decisions," Jau rnal of Finance, 32 (December 1977), 1467-1484.

Vermaelen, T., "Common Stock Repurchases and Market Signalling: An Empirical Study," Journal of Financial Economics, 9 (June 1981), 139-183.

Williamson, S., "The Moral Hazard Theo ry of Corporate Financial Structure: An Empirical Test," Unpublished Ph.D. Dissertation, MIT, 1981. 